\title{
The End of the Satrapies: The Date of Alexander IV's Death
}

\author{
By Harry Tolley*
}

The dearth of accurately datable documents from the time (323-c. 275 BCE) of Alexander the Great's Successors (also known as the Diadochi or Diadochoi) has contributed to uncertainty regarding the dating of key events from this time. In attempting to explain these inconsistencies, recent scholarship has focused on various different chronologies, some of which are described as "high" and "low." It would seem that particular importance would be assigned to the date of the end of the reign of Alexander IV, Alexander the Great's lone legitimate heir. However, little scholarly attention has been paid to the possible date of this very important transition that marked the end of the Macedonian Argead Dynasty. The current article attempts a thorough investigation of this event by examining remaining historical accounts and surviving contemporary government documents along with epigraphical evidence and archaeological discoveries. This information is then utilized in an attempt to arrive at a more precise date for the end of Alexander IV's reign and the end of the satrapies ruling in his name.

\section{Introduction}

The timeline of events regarding the Diadochi, the successors of Alexander the Great, has long been the subject of much scholarly speculation. Attempts to more clearly establish the dates of certain events seem to be dominated by two fields of thought: adherents of the "high chronology"1 and those of the "low chronology." ${ }^{2}$ Both of these chronologies have their problems, but both share the same logical focus in that they attempt to base the chronology on important events: the death of regents, great battles, etc. However, none of these chronologies focus on an event that should be considered one of the most important during the time of the Diadochi: the end of the reign of Alexander IV, son of Alexander the Great, an event which marked the end of the Macedonian Argead Dynasty. ${ }^{3}$ The purpose of this article is to address this

*Independent Researcher, USA.

1. A.B. Bosworth, The Legacy of Alexander: Politics, Warfare, and Propaganda under the Successors (Oxford: Oxford University Press, 2002).

2. R. Malcom Errington, "Diodorus Siculus and the Chronology of the Early Diadochoi, 320-311 B.C.," Hermes 105 (1977): 478-504; Edward M. Anson, "Dating the Deaths of Eumenes and Olympias," Ancient History Bulletin 20 (2006): 1-8; Edward M. Anson, "The Chronology of the Third Diadoch War," Phoenix, 60 (2006): 226-235.

3. For example, while it is a good introduction to the dating problem inherent in Diadochi studies, Tom Boiy's Between High and Low... does not mention the date of the death of Alexander IV. Thomas Boiy, Between High and Low. A Chronology of the Early Hellenistic Period. Oikumene Studien zur antiken Weltgeschichte, Bd. 5. (Frankfurt: Verlag Antike, 2007). Alexander Meeus' important reevaluation of the dating of events during the time of the Diadochi mentions Alexander IV's death only in passing (p. 89). Alexander Meeus, "Diodorus and the Chronology of the Third Diadoch War," Phoenix 66 (2012): 74-96. Part of this problem seems to be that most of the dating controversy does not cover events after $311 \mathrm{BCE}$. 
vacancy with a thorough investigation of the end of Alexander IV's reign. This will be done by making use of remaining historical accounts, surviving contemporary government documents, epigraphical evidence and archaeological discoveries. It is hoped that this investigation may provide a firmer date for the end of Alexander IV's reign and the end of the satrapies.

\section{The Demotic Papyri}

The dearth of documents from the time of the Diadochi has contributed to the modern scholarly reliance on histories written long after the events in question. ${ }^{4}$ An example of this can be found in the study of the extant papyri fragments from this time period. Of the five Greek papyri that are known to exist from this period, all are from the island of Elephantine and only one self-dates itself to the year it was written and names the rulers at that time. ${ }^{5}$ There are, however, a number of Demotic papyri from the time of the Diadochi that self-date and include the names of the rulers at that time. These papyri are from Egypt and were found in a necropolis outside the city of Thebes. The Demotic papyri are all government documents, written by government scribes and notaries. This should lend the papyri an air of authenticity regarding the information the papyri contain regarding Alexander IV, but this has not been the case. Part of this somewhat dismissive attitude may be due to that fact that, to date, no single study has examined a selection of the Demotic papyri that have a bearing on the reign of Alexander IV. When one is examining a single source with a "strange" date, it is easy to dismiss the source as an aberrance. However, when that source is viewed in its proper context as part of a collection of several sources that share the same tradition, the collection of sources becomes more difficult to dismiss.

4. Alexander IV is mentioned in one main historical account, the Bibliotheca Historica of Diodorus Siculus, which dates from the first century BCE. Apart from Diodorus, there are few surviving accounts of the time after Alexander the Great's death. The Roman historian Arrian, writing in the mid-2nd century CE, composed a 10-volume history of the time after Alexander's death entitled Events after Alexander. This work has not survived and is known only from a 9th century Byzantine epitome. Justin's 3rd century epitome of the writings of the 1st century Roman historian Gnaeus Pompeius Trogus includes several interesting pieces of information, but without being able to compare it to its original source, it is difficult to rely on. Several classical authors, including Quintus Curtius Rufus ( $1^{\text {st }}$ century CE), Plutarch (c. 50 CE-c. 120 $\mathrm{CE})$ and Pausanius ( $2^{\text {nd }}$ century CE) mention events involving Alexander IV, but have little information that is not in Diodorus.

5. This papyri is Papyrus Elephantine 1 (P. Berlin 13500). For more general information on the Elephantine papyri, consult: The Elephantine Papyri in English (Documenta et Monumenta Orientis Antiqui), ed. and trans. by Bezalel Porten, J. J. Farber, C. J. Martin, $2^{\text {nd }}$ ed. (Atlanta: SBL Press, 2011) 1-28. For more specific information on Papyrus Elephantine 1 see Porten and Farber 408-410. 


\section{Dra Abu el-Naga Papyrus 29-86-523B ${ }^{6}$}

This papyrus self-dates ${ }^{7}$ to the seventh year of Philip Arrhidaeus' reign as king, which would be the year $317 \mathrm{BCE}^{8}$ After Alexander the Great's death in $323 \mathrm{BCE}$, his generals agreed that the empire would be ruled jointly by Alexander's remaining male relatives: his half-brother Philip Arrhidaeus and Alexander's (then) infant son Alexander IV. ${ }^{9}$ Because Philip Arrhidaeus was of limited mental faculty and Alexander IV was a child, both potential kings were unable to govern their empire and thus their territories were split up among various satraps who governed on behalf of the two. Ostensibly, this arrangement would only last until the time that Alexander IV was old enough to rule. ${ }^{10}$

The full date of the papyrus is "year seven, month Tybi, of King Philip," which would be March, 317 BCE..$^{11}$ In an article on Papyrus 29-86-523B, entitled "A Deed of Gift in 317 B.C.,"12 Julius Reich explains that the first "year" of Philip Arrhidaeus' reign probably lasted only four to five months until the second year began. ${ }^{13}$ Reich explained that the reason for this was that the Demotic papyri followed the Egyptian tradition of a attributing a full year to a new king's first year as king. This first year would begin the moment he became king and last until the beginning of the Egyptian new year, regardless of whether an actual year had passed. According to Reich, the Egyptians dated

6. Unless otherwise noted, these papyri were originally translated and published by Nathaniel Julius Reich, in his journal Mizraim. For a detailed overview, see N. J. Reich, "The Papyrus Archive in the Philadelphia University Museum, 1" Mizraim 7 (1937): 11-19. For Dra Abu el-Naga Papyrus 29-86-523B, see Reich, "Papyrus," 13. Mustafa El-Amir lists this papyrus as "Ph. I, MIZ. II, pl. 3-4." The abbreviation "MIZ" refers to the volume of Mizraim where the papyrus was originally published. See Mustafa El-Amir, A Family Archive from Thebes (Cairo: Government Printing Offices, 1959), 1-6. El-Amir also included a chart which contained his listings compared to the numbers assigned some of the papyri when they were returned to Cairo in 1951. This papyrus is assigned the Cairo number 89,631. See El-Amir, x. Karl-Theodor (K. T.) Zauzich does not list this papyrus in his work Die Ägyptische Schreibertradition in Aufbau, Sprache und Schrift der demotischen Kaufverträge aus ptolemäischer Zeit, Band 1 (Wiesbaden: O. Harrassowitz, 1968). However, it is listed in a much later article entitled, "Papyri Demotische," in Lexikon der Aegyptologie 4.1 (Wiesbaden, 1980). Reich's work on these papyri is the most detailed and as a result most of the examination of dating, etc., will entail interacting with Reich rather than El-Amir or Zauzich.

7. This is a very important distinction to make. These papyri are self-dated by the person who wrote them in the fourth century BCE; the date is not an estimate by modern scholars.

8. Unless otherwise noted, translating and dating was originally done by N. J. Reich. Unless otherwise noted, El-Amir and Zauzich agree with Reich's dating.

9. Diodorus Siculus, Bibl. Hist. 17. 117.

10. It is important to note that the joint rule is never mentioned in the Demotic papyri. Philip Arrhidaeus is listed as king until his death, at which time Alexander IV is listed as king.

11. Reich dated the papyrus to a specific day: March 10, 317 BCE. See Reich, "Papyrus." 13.

12. Nathaniel Julius Reich, "A Deed of Gift in 317 B.C.," Mizraim, 2 (1936): 57-69.

13. Reich, "A Deed...," 58. 
Arrhidaeus' "year one" as beginning in $323 \mathrm{BCE}$, immediately after the death of Alexander the Great, ${ }^{14}$ with "year two" following soon after.

\section{Dra Abu el-Naga Papyrus 29-86-508 ${ }^{15}$}

The papyrus was written in the third year of Alexander IV's reign which would be the year 314 BCE. ${ }^{16}$ This was, therefore, three years after the death of both Alexander IV's uncle Philip Arrhidaeus and Philip's wife, the Illyrian princess Eurydice. ${ }^{17}$

This papyrus is invaluable to our study. Its existence (along with the material we have already covered regarding Dra Abu el-Naga 29-86-523B) demonstrates that once word reached Egypt about Philip Arrhidaeus' death (and this notification was apparently not long in coming), the Egyptian scribes started dating their documents with the first year of Alexander IV's reign. This papyri also further establishes that there is no indication of a "joint reign" tradition in the Demotic papyri. Philip Arrhidaeus was listed as king until his death in 317 BCE. Upon Philip's death, Alexander IV was listed as king and the calendar of years restarted with year one.

14. In the course of his article, Reich mentions another Demotic papyrus written during the reign of Philip Arrhidaeus that may be dated even later than Dra Abu el-Naga 29-86-523B. The papyrus in question is Bibliothèque nationale No. 249. Unfortunately, the papyrus is partially damaged and the exact month it was written in cannot be determined. However, according to Reich, the year in which it was written is visible, as is the name of Philip Arrhidaeus. Reich assumes that the papyrus, since Philip ruled until 317 BCE (six years following the Greek system, seven years following the Egyptian), was dated post mortem, but this is not necessarily the case. The papyrus could date from the early months of the eighth year of Philip's reign according to the Egyptian system, which would be the last few months of the seventh year according to the Greek system. This would match up well with the date given in Diodorus Siculus (Bibl. Hist. 19. 11) for the date of Philip Arrhidaeus' death: October or November 317 BCE. Reich realized this, but attempted to argue that he could somehow make out the month from the few marks that remained, but this seems uncertain. Even if accurate, Reich's dating of the papyrus to the third month of Philip Arrhidaeus' eighth year has little significance when compared to the length of Alexander IV's reign, as given in the Demotic papyri. See Reich, "A Deed...," 58, 59. For more information on Bibliothèque nationale No. 249, see K.T. Zauzich, "Papyri, Demotische, Paris," Lexicon der Ägyptologie, Lieferung 25 (Otto Harrasowitz: Wiesbaden, 1980), 862.

15. Reich, "Papyrus," 13-14. El-Amir lists this papyrus as "Ph. II, MIZ. III, pl. 1-2." In general, if a papyrus has been given a Cairo number by El-Amir, Zauzich will list it in parentheses after his listing. Thus, Zauzich lists this papryus as "Urkunde 2: P. Philadelphia 2 (= P. Kairo 89362)." See El-Amir, 7-12 and Zauzich, Schreibertradition, 12.

16. Reich dates the papyrus to the Egyptian month Pachons which is roughly parallel to July. Here as above, Reich dates the papyrus to an actual day: July 8, 314 BCE. In this particular instance, Reich is using the Egyptian system for regnal years. See Reich, "Papyrus," 13-14.

17. Eurydice is sometimes called Adea. Her mother was Philip II's daughter Cynane; thus Eurydice was the niece of both Alexander the Great and her husband Philip Arrhidaeus. Eurydice and Arrhidaeus were killed in 317 BCE by order of Olympias, Alexander IV's paternal grandmother (and Alexander the Great's mother). As Macedonia was already wracked by civil war, Philip's and Eurydice's deaths made the political situation in Macedonia even more chaotic. Olympias emerged as ruler for a time before being supplanted by Cassander. She was finally murdered by an angry mob of Macedonians. See Diodorus Siculus, Bibl. Hist., 19. 51 


\section{Dra Abu el-Naga Papyrus 29-86-509 ${ }^{18}$ and Dra Abu el-Naga Papyrus 29-86-512 ${ }^{19}$}

Both of these papyri are dated by Reich to the tenth year of Alexander IV's reign, which would have been the year $307 \mathrm{BCE} .^{20}$ It is with these papyri that we begin to enter controversial territory. ${ }^{21}$ According to Diodorus Siculus' account, while Cassander's army was fighting the forces loyal to Alexander the Great's mother Olympias, Olympias was killed by a group of vengeful Macedonians. $^{22}$ Cassander then had almost total control of Macedonia and almost as important - Alexander IV and his mother, the Bactrian princess Roxane, became Cassander's captives.

Knowing that he held the most dangerous pieces in the grand chess game played by Alexander the Great's former generals, Diodorus Siculus writes that Cassander had Alexander IV and Roxane imprisoned. ${ }^{23}$ Later, when he heard rumors that word was being spread throughout Macedonia that Alexander IV was old enough to become king, Cassander became frightened ( $\varphi \circ \beta \eta \theta \varepsilon i \varsigma)$ and had Alexander IV and Roxane murdered and secretly buried. ${ }^{24}$ According to Diodorus Siculus, these events took place in $311 \mathrm{BCE}$, in what would have been the seventh year of Alexander IV's solo reign. This, then, is the controversy: how could Alexander IV be given a tenth year of reign in Egypt when, according to Diodorus Siculus, he was murdered in his seventh year as king, in 311 BCE?

Julius Reich was also intrigued by the dates of these two papyri. However, his examination of them was unusual. In an article entitled, "A Notary of Ancient Thebes," Reich examined the dates of the papyri, but did so by writing a fictional recreation of a day in the life of an Egyptian notary, with Peteshe the Egyptian scribe who actually wrote (and signed) papyrus 29-86-509 - as

18. Reich, "Papyrus," 14-15. El-Amir lists this papyrus as "Ph. III, MIZ. VII, pl. 1-2." Zauzich lists it as "Urkunde 3: P. Philadelphia 3 (= P. Kairo 89363)." See El-Amir 13-16 and Zauzich, Schreibertradition, 12.

19. Reich, "Papyrus," 15. El-Amir lists this papyrus as "Ph. IV, MIZ. VII, pl. 3-4." Zauzich lists it as "Urkunde 96: P. Philadelphia 4." This papyrus is not given a Cairo number because it is still in possession of the Museum of the University of Pennsylvania. See El-Amir 17-21 and Zauzich, Schreibertradition, 74.

20. According to Reich (using the Egyptian system of regnal years) both papyri were written on different days in the month of Tybi: March, 307 BCE. Reich, "Papyrus," 14-15.

21. Primarily because it starts to become difficult to reason out the dating of the papyri when compared to the dates in Diodorus' account. After all, the oldest dated Greek document from Egypt (Porten and Farber 409), Papyrus Elephantine 1 (P. Berlin 13500), self-dates to 310 $\mathrm{BCE}$, and states that it was written "In the seventh year of the reign of Alexander, the son of Alexander, in the fourteenth year of the satrapship of Ptolemy in the month of Dios..." (Porten and Farber 408). However, it is much easier to believe that a scribe could make a one year mistake (311 BCE carrying over to 310 BCE) than the seven year discrepancy one finds in Dra Abu el-Naga Papyrus 29-86-509 \& 29-86-512.

22. Diodorus Siculus, Bibl. Hist., 19. 51.

23. Diodorus Siculus, Bibl. Hist., 19. 52.

24. Diodorus Siculus, Bibl. Hist., 19. 105. 
the central character. ${ }^{25}$ While it does not mention Alexander IV in the title, the focus of Reich's article is an attempt to explain how the Egyptian notary Peteshe could have made the "mistake" of dating a transaction during the tenth year of Alexander IV's reign.

After a brief recollection of the political situation in Alexandria under Ptolemy I, Reich shifts his focus to events that took place "away up the Nile at the ancient capital, Thebes... ." 26 According to Reich, Peteshe began writing the deed, but stopped long enough to address his customers, "He explained that as he had not been officially informed of the murder of Alexander (IV), he would ignore it altogether and date the document in the tenth year of the reign of Alexander IV." ${ }^{27}$ Reich has Peteshe explain his actions by reciting a number of things that the scribe had observed: "...a second reason for (his dating was) that Ptolemy, the Satrap, continued rebuilding part of the great Temple of Amon-Ra in Thebes in the name of Pharaoh Alexander (IV)... a third circumstance which made him doubt the truth of the story was that Ptolemy has ordered to be erected the great granite statue of Alexander (IV)." ${ }^{28}$ Finally, Reich (as Peteshe) reasons, "if the story were actually true and Alexander (IV) had in fact been murdered, he would not know how to date the document at all because the only method of dating the document which he knew was to write the year of the reigning Pharaoh, counting the years from the beginning of his reign. Therefore, to date the document at all, it was necessary for him to assume that Alexander (IV) was still Pharaoh." ${ }^{29}$

Reich then reproduces the text of papyrus 29-86-509 in its entirety and, finished with his pantomime as Peteshe, writes the following: "the interesting point to which I wish to call special attention is that the notary in dating his document as he did establishes the fact that although King Alexander IV was murdered in 311 B. C., business and official documents were dated as of his reign as late as 307 B. C." ${ }^{30}$ Reich continues, "This papyrus, therefore, besides its importance for other facts of history, forms a new proof that Ptolemy I Soter continued to rule in Egypt as Satrap in the name of the murdered King Alexander IV. It would seem that he officially concealed the murder of his overlord until he became Pharaoh of Egypt himself." ${ }^{31}$ This strange article by Reich provides the reader with more questions than answers, but the most important question to be raised is why Reich felt it necessary to participate in such a unusual exercise in order to arrive at such an unlikely scenario, all in an attempt to explain the dates of papyrus 29-86-509, and by proxy, 29-86-512.

25. N.J. Reich, "A Notary of Ancient Thebes," The Museum Journal (University of Pennsylvania) 14 (1923): 22-25. Papyrus 29-56-512 was also written by Peteshe, but is not covered in Reich's recreation of events.

26. Reich, "Notary," 23.

27. Reich, "Notary," 23.

28. Reich, "Notary," 23. Interestingly, a large temple to the Egyptian god Khnum was built on Elephantine and dedicated in the name of Alexander IV. See Bertha Porter and Rosalind L.B. Moss, Topographical Bibliography of Ancient Egyptian Hieroglyphic Texts, Reliefs and Paintings, vol. 5: Upper Egypt: Sites (Oxford: Clarendon Press, 1937), 227. Note that Alexander IV is here called "Alexander II (Alexander the Great was the first Pharaoh named Alexander)."

29. Reich, "Notary," 23.

30. Reich, "Notary," 24-25.

31. Reich, "Notary," 25. 
In response, it is important to note that 29-86-509 and 29-86-512 were written in the same year and month, but are two separate documents, written on different days. Reich certainly must have known this and also knew that this fact effectively eliminated the possibility of scribal error. Certainly, a scribe could make a mistake regarding a year or ruler once, but since both papyri were written by the same notary (Peteshe) on two separate occasions, this possibility seems highly unlikely.

Second, the existence of papyrus 29-86-523B, which describes itself as being written in the seventh year of Philip Arrhidaeus' reign (317 BCE) and papyrus 29-86-508, which self-dates itself to the third year of Alexander IV's reign (314 BCE), eliminated the possibility that the Egyptian scribes somehow backdated Alexander IV's reign into the time when he ruled as "co-regent" with his father's half-brother Philip Arrhidaeus. ${ }^{32}$ Reich found himself in a difficult situation. How could one account for the dates found on papyrus 29-86-509 and 29-86-512 and not disagree with both the account and the date of Alexander IV's death as described in Diodorus Siculus? After all, if one follows the dating in Diodorus Siculus, Alexander IV had been dead for four years when the deed was written. Perhaps out of desperation, Reich came up with the scenario described above: the Egyptians had "heard rumors" of Alexander IV's death in 311 BCE, but since no one else had declared themselves Pharaoh of Egypt, documents would continue to be dated under the reign of Alexander IV. ${ }^{33}$

Reich's theory regarding stubborn, literate Egyptians refusing to accept Alexander IV's death for some reason was recently dusted off (without citing Reich) by Jona Lendering, writing at livius.org: "Although in Babylonia and Egypt, people continued to date letters according to the regnal years of the boyking Alexander IV, the main result of the treaty (between the Diadochi in 311 BCE) was that Roxane and the twelve year old Alexander were killed: neither Cassander, nor his enemies could allow the boy to live. ${ }^{34}$ This statement is misleading, as the documents in question are not letters written by commoners ("people"), but rather government documents written by representatives of the governments in question; thus Reich's previous labyrinthine theorizing.

32. This "co-regent" explanation has been used by other scholars to attempt to explain aberrant dates for Alexander IV's reign, but in this particular case, the dating system utilized by the Demotic papyri do not allow for such convenient reasoning. For examples of the "co-regent" hypothesis, see Sidney Smith's excellent overview of various scholarly theories (prior to 1925) regarding the death of Alexander IV in his article, "The Chronology of Philip Arrhidaeus, Antigonus and Alexander IV," Revue d'Assyriologie et Archéologie, 22(1925): 179-197. Smith's own conclusions regarding the chronology, are, however, dated and should not be trusted. Also of note is that the card catalogue in the University of Pennsylvania's Museum which deals with the Demotic Egyptian papyri follows this erroneous "co-regent" hypothesis. Thus, the card for 29-86-509 and 29-86-512 dates them to 314/ 313 BCE.

33. Further, as we shall see below, according to the account of Diodorus, Ptolemy had declared himself king of Egypt in 311 BCE. Reich wants it both ways: he wants Diodorus to be correct and Peteshe to be correct. It is incredulous to suggest that an Egyptian official such as Peteshe would somehow follow his own impulses and continue to date government documents by the reign of the dead king Alexander IV. 2VitB8F.

34. Jona Lendering, "Alexander IV," Livius, last modified 21 April 2019, https://bit.ly/ 


\section{Louvre Demotic Papyrus $2427^{35}$ and Louvre Demotic Papyrus $2420^{36}$}

Both of these papyri are dated as being written in the thirteenth year of Alexander IV's reign: 305/ 304 BCE. ${ }^{37}$ Alexander IV would have been 18 or 19 years old. Both papyri are from Thebes and both deal with the sale of a house. El-Amir does not list these papyri. Zauzich, perhaps hoping to avoid controversy, lists the papyri and translates their contents, but spends very little time postulating as to what the dates could mean. ${ }^{38}$ N.J. Reich apparently did not know of these papyri or, if he did, chose not to deal with them. In Reich's defense, they are notably difficult to deal with. How does one reason out the information that, in Egypt at least, Alexander IV was still considered to be king up until the time he would have been physically old enough to rule on his own? T.C. Skeat, a contemporary of Reich's who had an article published in Reich's journal Mizraim, ${ }^{39}$ knew of the two Louvre papyri. It was Skeat who came up with an inventive -and influential - way of dealing with the controversial information they contained.

\section{T.C. Skeat and "The Secret Kingship" Theory}

In his short and well-organized book, The Reigns of the Ptolemies, Skeat at times seems to accept the dubious scenario that the Egyptian scribes knew Alexander IV died in $311 \mathrm{BCE}$, but continued to date documents by his reign for seven more years. At one point, Skeat writes, "in Egypt, the demotic scribes refused to accept (Alexander IV's death)...," an occurrence which Skeat describes as a "curious phenomenon." 40 However, in the course of his investigation, Skeat invented an influential scenario regarding the late dating of the papyri. He theorized that Ptolemy openly gave himself the title of king-as would be visible on the government documents - in 304 BCE, but had been acting as king ever since he was secretly informed about the death of Alexander IV, years earlier: "In 304 (BCE) then, Ptolemy became king in name as well as

35. Reich does not mention this papyrus. El-Amir knows of this papyrus, but only lists it in a footnote. See El-Amir, A Family Archive from Thebes, 20. Zauzich lists this papyrus as "Urkunde 97: P. Louvre 2427." See Zauzich, Schreibertradition, 74. Zauzich writes that he used photographs for his investigation of Louvre 2427 and Louvre 2440: "Für die folgende Umschrift wurde ein Foto benutzt." This indicates that his information should be more reliable than E. Révillout's handwritten copy of these two papyri. See Zauzich, Schreibertradition, 12 and 74. For Révillout's "handcopy" of Louvre 2427 and 2440, see Eugène Révillout, Chrestomathie Démotique, vol. 3 (Paris: F. Viewig, 1880), 219-223, 479-481.

36. Reich does not mention this papyrus. El-Amir does not mention this papyrus. Zauzich lists this papyrus as "Urkunde 4: P. Louvre 2440." See Zauzich, Schreibertradition, 12-13.

37. Dating/ translation of these papyri by Zauzich. See Zauzich, Schreibertradition, 12 and 74.

38. Zauzich, Schreibertradition, 12 and 74.

39. Theodore Cressy (T.C.) Skeat, "A Greek Mathematical Tablet," Mizraim, 3(1936): 1825 .

40. Theodore Cressy Skeat, The Reigns of the Ptolemies, $2^{\text {nd }}$ edition, Münchener Beiträge zur Papyrusforschung, 39 (Munich: C.H. Becke, 1968), 29. 
in deed." ${ }^{41}$ Skeat lists several other parallels from other parts of the empire that seem to back this date up, including the "Babylonian Tablets," which first give the title "king" to the satrap Seleucus in the same year of 304 BCE. ${ }^{42}$

This "secret kingship" scenario has influenced several other scholars in the decades since it was first proposed. Erhard Grzybek, ${ }^{43}$ Ludwig Koenen, ${ }^{44}$ Reinhold Merkelbach, ${ }^{45}$ Günther Hölbl ${ }^{46}$ and Tom Boiy ${ }^{47}$ all follow this scenario. However, few scholars have attempted to explain exactly why the satraps waited so long to openly declare themselves kings. Hölbl, however, does attempt an explanation of Ptolemy's reasoning and it is quite inventive: "The long period of time between (Ptolemy's) adoption of the title of (king) and the establishment of a calendar on the basis of his reign...clearly shows the coronation ceremony was planned in every detail." ${ }^{48}$ In other words, Ptolemy held off declaring himself king to minutely plan his coronation party!

All of these theories, old and recent, revolve around attempting to somehow reason out the differences in dating between the Demotic papyri and the historical account of Diodorus. However, when one examines the events surrounding Alexander IV and the movement of the Diadochi from satraps to kings in the writings of Diodorus, one discovers a problem with the date originally given for the end of the satrapies. In his account, Diodorus records the regnal events taking place not once but twice.

\section{Diodorus' Dates Regarding the End of the Satrapies}

As we discussed previously, according to Diodorus' account, Cassander ordered the deaths of Alexander IV and Roxane in 311 BCE and ordered the murderer, Glaucias, to keep the deaths secret. In the same section, Diodorus writes that Cassander, Lysimachus, Ptolemy and Antigonus were all relieved by Alexander IV's death, "for from that point onward, with no living heir to inherit the kingdom (of Alexander the Great), each of those rulers over cites or nations had ambitions for royal power and they ruled the territories that had been placed under their authority as if it were a kingdom... ." ${ }^{49}$ In other words, according to Diodorus Siculus, after hearing of Alexander IV's death,

41. Skeat, Ptolemies 28.

42. Skeat, Ptolemies 28.

43. Erhard Grzybek, Du Calendrier Macédonien au Calendrier Ptolémaïque: Problèmes de Chronologie Hellénistique (Basel: F. Reinhardt, 1990), 90, $96 f$.

44. Ludwig Koenen, "The Ptolemaic King as a Religious Figure," Images and Ideologies: Self-Definition in the Hellenistic World (Berkley: University of California Press, 1993), 57.

45. Reinhold Merkelbach, "Zur ENKATOXH im Sarapeum zu Memphis," Zeitschrift für Papyrologie und Epigraphik, 103(1994): 293-296.

46. Günther Hölbl, A History of the Ptolemaic Empire (London: Routledge, 2001)

47. Boiy 89, 90.

48. Hölbl 32.

49. Diodorus, Bibl. Hist., 19.105. 
Alexander the Great's remaining generals no longer ruled as satraps but instead openly ruled as kings of their respective "cities or nations" in $311 \mathrm{BCE}^{50}$

In a later chapter, Diodorus spins a second tale detailing the events behind the Diadochi beginning to rule as kings. This second scenario is set in $307 \mathrm{BCE}$ and holds that after Antigonus (Monophthalmus) and his son Demetrius defeated Ptolemy's forces in a naval battle near Cyprus, Antigonus and Demetrius decided to declare themselves kings. Diodorus remarks that "the remaining lords ( $\delta v v \alpha ́ \sigma \tau \alpha \mathrm{\iota}$ ) were jealous of (Antigonus and Demetrius) and so they also began to call themselves kings." ${ }^{51}$ This included Ptolemy, Seleucus, Lysimachus and Cassander. This seems to be in contrast to what Diodorus recorded previously regarding events after Alexander IV's purported death in 311 BCE.

Why the discrepancy? It is possible that Diodorus had at his disposal two different accounts of exactly when the Diadochi moved from acting as satraps to openly acting as kings. Both scenarios are reasonable: the death of Alexander IV effectively did away with the need for a "satrap" or a guardian ruler and if one "lord" began calling himself "king," the others would follow suit. There is, however, cause for concern. We must not forget that this very important movement from satrap to king occurs twice in Diodorus Siculus' account, and dates for the events are contradicted by the reliable Demotic Egyptian Papyri. This raises the possibility that both dates given in Diodorus are incorrect, especially when further evidence is examined. ${ }^{52}$

\section{The "Babylonian Tablets"}

A series of records from Babylon-known by the blanket term "Babylonian Tablets"- exist which provide several lists of dates of the reigns of many kings, both Babylonian and Hellenistic. These lists were written in cuneiform, inscribed on clay tablets. Two of these tablets are important to our study: the tablet known as the Diadochi Chronicle (BCHP 3; ABC 10, Chronicle 10) and the tablet known as Babylonian King List of the Hellenistic Period ("King List 6," BM 35603, Sp. III 113). To understand the Babylonian King List..., one must first read the Diadochi Chronicle.

In the Diadochi Chronicle, we learn that when Seleucus took over Babylon, he announced that he was ruling as co-regent for Alexander IV. Therefore, dates for the reign of Seleucus would also be dates for the reign of Alexander IV: "[Seleu]cus spoke as follows: 'Year 7 of Antig[onus the general

50. Worthington's By the Spear: Philip II, Alexander the Great, and the Rise and Fall of the Macedonian Empire (Oxford: Oxford University Press, 2014) follows this scenario. See: Ian Worthington, By The Spear: Philip II, Alexander the Great, and the Rise and Fall of the Macedonian Empire (Oxford: Oxford University Press, 2014), 300, 327.

51. Diodorus, Bibl. Hist., 20. 52.

52. For a very good overview of several lines of criticism regarding the reliability of Diodorus' dates, see Edward M. Anson, "Diodorus and the Date of Triparadeisus," The American Journal of Philology, 107(1986): 208-217; Erich S. Gruen, "The Coronation of the Diadochoi," The Craft of the Ancient Historian (Lanham: University Press of America, 1985), 253-27 and Meeus, 76-93. 
as year 6 of Alexander, son of] [Reverse iv.4] idem [i.e. Alexander] and Seleucus the general, you will count."' ${ }^{53}$ In this section, the tablet claims Seleucus himself ordered the chroniclers to count year seven of the reign of Antigonus as year six of the co-reign of Seleucus and Alexander IV. This command is dated to $311 \mathrm{BCE}$, which means that, according to the altered Babylonian record, Alexander IV was listed as beginning his reign in $317 \mathrm{BCE}$. The co-regent status of Seleucus and Alexander IV was continued throughout the remainder of the Chronicle of the Diadochi tablet, which breaks off at the year 309 BCE.

Further information about this time period can be found in the Babylonian King List... . This tablet reads, "[Obverse 3] For [n] years there was no king in the country. Antigonus, [Obv.4] general-in-chief of the army, ruled the land." ${ }^{15}$ This is the seven years referred to in the Chronicle of the Diadochi, which Seleucus ordered to be counted as six years. The Babylonian King List... continues, "[Obverse 5] Alexander [IV], son of Alex[ander III]: 6 years. ${ }^{55}$ [Obv.6] Year 7, which is year 1: Seleucus (I Nicator was) king." ${ }^{56}$ Here, the translator includes the following note: "this means: The 7th year of the Seleucid Era $(305 / 304 \mathrm{BCE})=$ the first year of Seleucus I Nicator as king." ${ }^{57}$ Thus, according to the information from Babylon, Seleucus reigned as co-regent, or satrap, in the East until the year 305/304 BCE when he openly ruled as sole regent, or king. ${ }^{58}$ This date matches up with the date of the last year of Alexander IV's reign given in the Demotic papyri. It is important to note that the Babylonian dating is independent of the Egyptian scribal tradition.

\section{The Parian Chronicle}

The date of 305/304 BCE as the year when Seleucus openly declared himself king has a parallel in a source that claims Ptolemy first declared himself king in that same year. This information comes from Greece, in a section of information found on the lower register of the Parian Chronicle. Here, the account states that Ptolemy "assumed the diadem" in the year 305/ 304 BCE. ${ }^{59}$ This reference is compelling for a number of reasons, but

53. Translation of this section by I.L. Finkel, R.J. van der Spek and R. Pirngruber. This material is to be published in Babylonian Chronographic Texts from the Hellenistic Period (BCHP; Writings of the Ancient World, forthcoming in 2020). At the time the current article was written, the translation can only be found at: https://bit.ly/2JCLVqF.

54. Translation by R.J. van der Spek. This material will also be included in Babylonian Chronographic Texts from the Hellenistic Period, but currently can only be found at https://bit.ly/2YtBmuh.

55. After this line, the translator has entered a "?" which may mean the date is less than certain.

56. Tran.by: van der Spek.

57. Note by van der Spek.

58. Boiy claims that the Babylonian Tablets provide Alexander IV with "several posthumous years." After this brief remark, Boiy provides no other explanation for this practice on the part of the Babylonians, except to lump this occurrence in with the dates from the Demotic papyri. Boiy, 90 .

59. FGrHist 239, B 23. 
primarily because the Parian Chronicle dates from 264/ 263 BCE, roughly one generation after the events in question. Also of note is that the information comes from yet another Greek source and a source that can definitively be described as being independent of the Egyptian scribal tradition. ${ }^{60}$

\section{The "Canon of Ptolemy"}

Another reference to $305 / 304$ BCE as the year that Ptolemy declared himself king of Egypt dates from much later in history. It is the so-called "Canon of Ptolemy," a list of the years each Egyptian pharaoh or king ruled. ${ }^{61}$ The list was compiled (or possibly copied directly) by Claudius Ptolemaeus (a.k.a. Ptolemy), a well-known Egyptian mathematician and astronomer (among other achievements) whose floruit was the $2^{\text {nd }}$ century $\mathrm{CE}^{62}$ The list states that Ptolemy I's reign began in 305/304 BCE and, more tellingly, lists the years for Alexander IV's reign as $317 \mathrm{BCE}$ to $305 / 304 \mathrm{BCE}$. This is, of course, yet another reference to 305/304 BCE as the end of Alexander IV's reign.

\section{Eusebius of Casarea's Chronicle and Porphyry of Tyre}

Another reference to the above dates for the end of the satrapies can be found in the Chronicle of the Christian historian Eusebius of Caesarea. Eusebius based his description of Alexander the Great and the Diadochi's activities in Egypt on a now lost historical account that Eusebius attributes to someone named Porphyry (Porphyrius). ${ }^{63}$ Apparently, this was the pagan philosopher Porphyry of Tyre (c. $234 \mathrm{CE}$ - c. $304 \mathrm{CE}$ ). According to the account preserved by Eusebius, Philip Arrhidaeus succeeded Alexander the Great in 324 BCE and a year after this event, Ptolemy travelled to Egypt and became satrap (323/ 322

60. The Parian Chronicle (also known as The Parian Marble and Marmor Parium) was discovered on Paros, an island in the Cyclades chain. The chronicle ceases its dating with the reign of an Athenian Archon named Diognetus (3rd Century BCE).

61. The list is known by a number of names including, "The Canon of Kings," "Ptolemy's Canon" and "Canon Basileōn." For a relatively recent reconstruction and translation of the Canon see G.J. Toomer, Ptolemy's Almagest (Princeton: Princeton University Press, 1998), 1011. The list was also part of a group of documents Ptolemy composed known as the "Handy Tables" or "Procheiroi Kanones." They are partially preserved in the writings of Theon of Alexandria. For a recent study of these tables, see Anne Tihon, "Theon of Alexandria and Ptolemy's Handy Tables," Ancient Astronomy and Celestial Divination, ed. N. M. Swerdlow (Cambridge: MIT Press, 1999), 357-369.

62. Skeat claims that the Canon contained information that came directly from the Egyptian Demotic Scribes. He writes, "the system followed is that of the demotic scribes; rarely used by the Greeks..." (italics by Skeat; see Skeat 5). As we have demonstrated, statements such as this no longer hold up to scrutiny.

63. Currently, only fragments remain of Eusebius' Chronicle (also known as the Chronicon) in Greek. It was preserved in Armenian and was finally brought back to the attention of western scholars in the late 18th and early $19^{\text {th }}$ century. For a full account of this fascinating story, see Alden Mosshammer, The Chronicle of Eusebius and the Greek Chronographic Tradition (Lewisberg: Bucknell Press, 1979). 
BCE) ${ }^{64}$ The account mentions that Arrhidaeus reigned for seven years before he was murdered by Olympias, Alexander the Great's mother. ${ }^{65}$ Importantly, the account gives separate dates for the reign of Ptolemy in Egypt as satrap and as king: Ptolemy reigned as satrap in Egypt for 17 years and then ruled with the title of king for 38 years. ${ }^{66}$ Therefore, this set of dates also indicates that Ptolemy gave himself the title of king in the year 305/ 304 BCE.

\section{The Royal Macedonian Tombs of Vergina}

These dates bring us to investigating the discovery of the royal Macedonian cemetery of Aegae, near the modern Greek village of Vergina, in the 1970's. ${ }^{67}$ The find was remarkable on a number of levels. Its excavation revealed the first known tomb complex of the Macedonian royal family; the family of Alexander the Great. There were three tombs found in the complex: Tomb I had been broken into and looted at some point in the past, but Tombs II and III were undisturbed and had interiors richly appointed with gold, silver and other precious objects.

It has recently been determined that Tomb I contained the inhumed (not cremated) bones of three individuals: a man in his late forties, a woman in her late teens and a newborn of indeterminate gender or specific age. ${ }^{68}$ Tomb II contained the cremated remains of a man in his late thirties and the cremated remains of a woman in her twenties. ${ }^{69}$ Tomb III contained cremated remains of one individual. ${ }^{70}$ The remains were found in a solid silver hydria that had been

64. .H. Petermann and A. Schöne, eds. and trans., Euesebi Chronicorum Libri Duo, $3^{\text {rd }}$ ed. (1886; Zurich: Weidmann, 1999), 230-233.

65. Eusebi Chronicorum 231.

66. See: Mosshammer, 50-80. Eusebius' Chronicle and the Chronicon Paschale (written in the early $7^{\text {th }}$ century CE) are in agreement that Ptolemy was king of Egypt for forty years, but Eusebius' Chronicle contains the extra information that Ptolemy turned the kingdom over to his son Ptolemy II for the last two years of his reign, thus technically making Ptolemy's solo reign 38, not 40 years. For an excellent introduction to the Chronicon Paschale, see Michael Whitby and Mary Whitby, "Introduction," Chronicon Paschale 284-628 AD (Liverpool: Liverpool University Press, 1989), ix-xxix. Since there is general agreement between the Chronicle and the Chronicon Paschale on this point (and many scholars agree that the Chronicon Paschale was at least partially dependent on Eusebius' Chronicle for its dating), we have chosen not to examine the Chronicon Paschale separately regarding this particular inquiry.

67. The account by the man who discovered the tombs, Professor Manolis Andronicus, is still the best. See Vergina: the Royal Tombs and the Ancient City (Athens: Ekodotike Athenon, 1984).

68. Antonis Bartsiokas, Juan-Luis Arsuaga, Elena Santos, Milagros Algaba, and Asier Gómez-Olivencia, "The Lameness of King Philip II and Royal Tomb I at Vergina, Macedonia," Proceedings of the National Academy of Sciences of the United States of America 112, no. 32 (2015): 9844-9848. There are, however, some who have misgivings about this study. See: Kristina Killgrove, "Twisted Knee Might Identify Alexander The Great's Father, But Some Are Skeptical," Forbes July 20, 2015, https://bit.ly/2LDw2CV.

69. Bartsiokas "The Lameness...," 9844-9846; Nikolaos (N.I.) Xirotiris and Franziska Langenscheidt, "The Cremations from the Royal Macedonian Tombs of Vergina," Archaiologike Ephemeris 157(1981): 142-160.

70. Andronicus 212; Bartsiokas "The Lameness..." 9844-9846; Xirotiris and Langenscheidt 157. 
crowned with a solid gold wreath or crown of oak leaves. The remains were wrapped in a purple cloth. ${ }^{71}$ Several intact and well preserved bones and teeth were found extant from the cremation, and, after examination, the occupant of Tomb III was estimated to have been fifteen to seventeen years old. ${ }^{72}$ Tomb III was determined to have been constructed after Tombs I and II; evidence was found that its construction disturbed the locus of Tombs I and II. ${ }^{73}$

Previous opinion varied as to the occupants of the Tomb I: some scholars claimed it belonged to Philip II, others that it belonged to Philip Arrhidaeus. ${ }^{74}$ A recent comprehensive reexamination of the occupants of Tomb I, utilizing new forms of technology now available to osteologists, have determined that the occupants of Tomb I were probably Philip II, his young (and recent) wife Cleopatra and their newborn daughter. ${ }^{75}$ This identification means that the inhabitants of Tomb II are Philip Arrhidaeus and Eurydice. ${ }^{76}$ The lone occupant of Tomb III was initially difficult to identify, primarily due to the researchers' reliance on the dating of Diodorus Siculus. How could the bones of a young man fifteen to seventeen years old possibly be those of Alexander IV when Diodorus claims Alexander IV died at a much younger age? Regardless, it now seems clear that the young man's remains found in Tomb III are those of Alexander IV; this conclusion came in spite of the dates given for Alexander

71. Andronicus 212.

72. Andronicus 231; Bartsiokas "The Lameness..." 9844-9846; Xirotiris and Langenscheidt 157.

73. Andronicus 224.

74. Antonis Bartsiokas has long been a proponent of the theory that the remains from Tomb I are Philip II. His research on the topic is not limited to the 2015 publication cited above. See also: "The Eye Injury of King Philip II and the Skeletal Evidence from the Royal Tomb II at Vergina," (Science 21 Apr 2000): 511-514, Angela M.H. Schuster, "Not Philip II of Macedon: An Interview with Antonis Bartsiokas," Archaeology (April 20, 2000), https://bit.ly/2VnHXob; and Philip Chang, "New Controversy Over Occupant of Ancient Tomb," The New York Times (April 25, 2000), https://nyti.ms/2WKnFqi. Bartsiokas also participated in a published experiment that demonstrated how the large wound found on a male leg bone from Tomb I can be recreated on a cadaver, thus further demonstrating that the damage to the leg bone found in Tomb I matches historical accounts of a war injury of Philip II. See: Nicholas J. Brandmeir, Russell A. Payne, Elias B. Rizk, R Shane Tubbs, Juan Luis Arsuaga, Antonis Bartsiokas, "The Leg Wound of King Philip II of Macedonia," Cureus Journal of Medical Science, 10, no. 4(2018): e2501. https://bit.ly/2VBXCVP. It must be noted that the Arrhidaeus/ Tomb II theory is convincing as it would necessarily follow that the female occupant of Tomb II is Philip Arrhidaeus' wife, the princess (and woman warrior) Eurydice and would explain the profusion of weapons in the antechamber section of Tomb II where the female remains were found. For more information see: Elizabeth Donnelly Carney, "Commemoration of a Royal Woman as a Warrior: The Burial in the Antechamber of Tomb II at Vergina," Syllecta Classica, 27(2016): 109-149. Regardless, a recent article once again claims that Philip II, not Arrhidaeus, is the inhabitant of Tomb II. See: Theodore G. (T.G.) Antikas and L.K. Wynn-Antikas, "New Finds from the Cremains in Tomb II at Aegae Point to Philip II and a Scythian Princess," International Journal of Osteoarchaeology 26 (2016): 682-692. It is worth mentioning that Andronicus, the archeologist who discovered the Vergina tombs, believed Philip II was the occupant of Tomb II: Andronicus, 226-231.

75. Bartsiokas 9844-9848.

76. Bartsiokas 9844-9848. See also: Eugene N. Borza and O. Palagia, "The Chronology of the Macedonian Royal Tombs at Vergina," JDAI, 122 (2007): 81-125 
IV's life in Diodorus Siculus. ${ }^{77}$ As one might expect, the dating of the bones found in Tomb III have also been the subject of some controversy. ${ }^{78}$ Regardless, the bones in Tomb III most likely belong to Alexander IV, and the estimated developmental age of the skeletal remains indicate that he died in the 305/304 BCE age range.

\section{Updating the "Secret Kingship" Theory}

The information above, taken from many different sources from many different areas all over the Empires of the Successors, all point to 305/304 BCE for the end of Alexander IV's reign. Accepting this information is nothing new; many scholars now adhere to Skeate's "secret kingship" theory, a clever way to blend Diodorus' date for Alexander IV's death with the well-established, nonDiodorus date of 305/304 BCE for the end of the satrapies. However, the material information revealed by the Vergina tombs is so intriguing and difficult to dispute that it allows us to propose a new theory: the satraps ruled as kings-without formally declaring themselves kings - while Alexander IV was regent in name only and described as such on government documents. During this time, Alexander IV lived a guarded existence (but was alive), he grew up and when he reached the age of 18 (or came close to that age), he died in Macedonia.

This theory is not so different from the "secret kingship" theory; it merely blends in the relatively new archaeological evidence regarding the bones of the occupant of Vergina "Tomb III" with the already existent theory. One wonders, however, if there are any other pieces of evidence that could lend further credence to this new theory. For further evidence, one need only further examine the Vergina tomb complex and also the numismatic records of Alexander IV's reign from the kingdom in which he and his mother were being held captive: Macedonia.

The existence of Tomb III rules out a secret burial for Alexander IV, like that of which Diodorus writes. The construction of a new tomb that bordered on, and actually damaged the dirt around the tomb of Philip would not have gone unnoticed by the Macedonian populace. It is important to remember that the people of Macedonia worshipped Philip II and his family as gods. We see vivid proof of this with the "heroon" or permanent sacrificial shrine Andronicus

77 .Andronicus 231; Bartsiokas "The Lameness..." 9847; Xirotiris \& F. Langenscheidt 142-160 and Winthrop Lindsay Adams, "Cassander, Alexander IV and the Tombs at Vergina," The Ancient World, 22 (1991): 27-33.

78. Jonathan Musgrave has written several articles and rebuttals to demonstrate his belief that the skeletal remains in Tomb III were much younger than Xirotiris \& Langenscheidt's estimations, but these are clearly aimed at propping up his belief that Tomb II contained the bones of Philip II, not Arrhidaeus. See "Dust and Damn'd Oblivion: A Study of Cremation in Ancient Greece," The Annual of the British School at Athens, 11 (1990): 271-299. See also Jonathan Musgrave," The Human Remains from Vergina Tombs I, II and III: An Overview," Ancient World, 22 (1991): 3-9. On page 3 of this article, Musgrave wrote that his goal in researching the bones was to "persuade you that the bones from Tomb II belonged to Philip II and (one of his wives)." 
found in the strata directly above Tomb II at Vergina. ${ }^{79}$ Granted, the royal cemetery of Aegae was approximately two kilometers from the town of Aegae, but the heroon above Tombs I \& II would have been regarded as sacred and work being done around it to construct Tomb III could not have happened until after Alexander IV's death had been announced. In other words, it is difficult to believe that the people of Macedonia would have allowed anyone outside the deified Philip II's deified family to be buried in the royal cemetery of Aegae. And, again, it is important to mention that the wealth and size of the tomb indicates its royal status. Another compelling point is the fact that numerous attestations for the practice of worship sacrifices were found in situ above Tomb III; clearly an indication of the occupant of the tomb being worshipped as divine after his entombment. ${ }^{80}$

The contents of Tomb III also offer compelling evidence that Alexander IV did not die in 311 BCE. The most telling items are the objects in the southwest corner: a linen cuirass, bronze greaves and a composite pectoral. ${ }^{81}$ These indicate the possessions of an adolescent being trained in the arts of war. According to Macedonian custom, this would have begun at the age of 14 when male members of the royal family were made "royal pages" and began to follow the king around on hunts and military maneuvers. ${ }^{82}$ Further proof of this comes from the two wreaths found in the tomb. The wreath of myrtle flowers and terracotta berries found near the southwest corner is the symbol of a young king. ${ }^{83}$ In contrast, the wreath that crowned the silver hydria (in which the cremated remains were found) was a gold wreath of oak leaves; the oak being the sacred tree of Zeus. It seems clear that this was Alexander IV's crown, possibly given to him when he became a royal page. ${ }^{84}$ Also of importance are the two cavalry spear-heads found on the same table as the hydria and crown. ${ }^{85}$ These must have been used by the young king on his expeditions as a royal page.

Numismatic evidence seems to back up the theory that Alexander IV lived long enough to become a royal page. Although at the present only silver and bronze Macedonian coins have been found from his reign, there are a wide variety of different engravings on the coins. ${ }^{86}$ Different bronze coins feature: the head of Apollo and on the reverse a horse and rider; the head of a young Herakles (or is this Alexander IV?) and on the reverse a club and bow; the Macedonian star and a plumed helmet on the reverse. Silver coins feature what may be a portrait of Alexander $\mathrm{IV}^{87}$ on the obverse and vary between three

79. Andronicus 65.

80. Andronicus, 224.

81. Andronicus 217.

82. See N.G.L. Hammond and G.T. Griffith, A History of Macedonia, vol. II (New York: Oxford, 1979), 168f, 396, 401 and N.G.L. Hammond and F.W. Walbank, A History of Macedonia vol. III (New York: Oxford, 1988), 167.

83. Andronicus 82.

84. It is significant to note that of the Greek gold wreaths that have been discovered intact so far, only three are oak and two of the three come from the tombs at Vergina.

85. Andronicus 82.

86. Hugo Gaebler, Die antiken Munzen von Makedonia und Paionia, vol. 2 (Berlin: Walter de Gruyter, 1935), 163

87. See: Hammond and Walbank, 162-163; and Gaebler, 163. 
images on the reverse: a horse and rider, a spear head, or a three-pronged weapon. The depiction of a horse, spear and other weapon may be indicative of the young king's status as a page.

How did Alexander IV die? Was it murder? On this subject, the historical tradition seems most probable. After all, Alexander the Great's enemies had no problem murdering Alexander's older son (and thus Alexander IV's halfbrother) Herakles many years before the death of Alexander IV. ${ }^{88}$ One may speculate all one wishes regarding the how and when, but the why was never in any doubt: retention of power.

\section{Conclusion}

In conclusion, we are compelled to state that, counter to the dating one finds in Diodorus, the satraps did not declare themselves kings in either the year $311 \mathrm{BCE}$ or the year $307 \mathrm{BCE}$. Instead, based on the excellent chronological information found in the Demotic Egyptian papyri-and corroborated by information from several contemporary, non-Demotic sources and discoveries from different locations around the Mediterranean-it seems much more likely that satraps ruled for Alexander IV until the year 305/304 BCE and then began to refer to themselves as kings. It further seems clear that the event which led to the satraps declaring themselves kings was the death of Alexander IV. We can therefore state with a good degree of certainty that both Alexander IV's death and the end of his reign should be dated to 305/304 BCE.

There is no controversy in suggesting that the satraps did rule independently in Alexander IV's stead. However, the amazing discovery of the royal Macedonian cemetery at Vergina and the estimated age of Alexander IV's physical remains allows us to suggest a new scenario: rather than rule as "secret kings" from 311-305/304 BCE, the satraps simply continued to do what they had done all along: rule independently. When King Alexander IV died in $305 / 304 \mathrm{BCE}$, the satraps logically chose the news as the right time to openly declare themselves the new kings of an already fragmented Alexandrian Empire.

We have demonstrated that the Demotic Egyptian scribes did not, in the words of Skeat, "refuse to accept" the death of Alexander IV. ${ }^{89}$ We can now state without reservation that maintaining the reign of Alexander IV in government documents was not a "curious phenomenon" somehow limited to the Demotic Egyptian scribes. ${ }^{90}$ Also, these scribes also did not carry over the dating from Philip Arrhidaeus' reign into the reign of Alexander IV. Further, we must regard as incorrect Reich's assumption that it is a "fact that although King Alexander IV was murdered in 311 B. C., business and official documents (from Egypt) were dated as of his reign as late as 307 B. C."11

88. See: WW Tarn, "Herakles son of Barsine," Journal of Hellenic Studies, 41 (1921): 1828; and also Hammond and Walbank, 95-98.

89. Skeat, 29.

90. Skeat, 29.

91. Reich, "Notary," 24-25. 
Instead, what we see in the Demotic papyri is the preservation of information that reflects a tradition found throughout the Hellenistic world. Namely, that the life of the young king Alexander IV-and thus also his symbolic reignended in 305/304 BCE.

\section{Bibliography}

Adams, Winthrop Lindsay. "Cassander, Alexander IV and the tombs at Vergina." The Ancient World, 22(1991): 27-33.

Andronicus, Manolis. Vergina: the Royal Tombs and the Ancient City. Athens: Ekodotike Athenon, 1984.

Anson, Edward M. "Diodorus and the date of Triparadeisus." The American Journal of Philology, 107(1986): 208-217.

Anson, Edward M. "Dating the deaths of Eumenes and Olympias." Ancient History Bulletin, 20(2006): 1-8.

Anson, Edward M. "The chronology of the third Diadoch war." Phoenix, 60(2006): 226-235.

Antikas, Theodore G. (T.G.) and L.K. Wynn-Antikas. "New finds from the cremains in tomb II at Aegae point to Philip II and a Scythian princess. International Journal of Osteoarchaeology 26(2016): 682-692.

Boiy, Thomas. Between high and low. A chronology of the early Hellenistic period. Oikumene Studien zur antiken Weltgeschichte, Bd. 5. Frankfurt: Verlag Antike, 2007.

Bosworth, A.B. The legacy of Alexander: politics, warfare, and propaganda under the Successors. Oxford: Oxford University Press, 2002.

Brandmeir, Nicholas J., Russell A. Payne, Elias B. Rizk, R Shane Tubbs, Juan Luis Arsuaga, Antonis Bartsiokas. "The leg wound of King Philip II of Macedonia." Cureus Journal of Medical Science, 10, no. 4(2018): e2501. https://bit.ly/2VB XCVP.

Bartsiokas, Antonis. "The eye injury of King Philip II and the skeletal evidence from the royal tomb II at Vergina." Science, 21(2000): 511-514.

Bartsiokas, Antonis, Juan-Luis Arsuaga, Elena Santos, Milagros Algaba, and Asier Gómez-Olivencia. "The lameness of King Philip II and royal tomb I at Vergina, Macedonia." Proceedings of the National Academy of Sciences of the United States of America 112, no. 32(2015): 9844-9848.

Borza, Eugene N. and O. Palagia. "The chronology of the Macedonian royal tombs at Vergina." JDAI, 122(2007): 81-125.

Chang, Philip. "New controversy over occupant of ancient tomb." The New York Times (April 25, 2000). https://nyti.ms/2WKnFqi.

Donnelly Carney, Elizabeth. "Commemoration of a royal woman as a warrior: the burial in the antechamber of tomb II at Vergina." Syllecta Classica 27(2016): 109149.

El-Amir, Mustafa. A Family Archive from Thebes. Cairo: Government Printing Offices, 1959.

Errington, R. Malcom. "Diodorus Siculus and the chronology of the early Diadochoi, 320-311 B.C." Hermes 105(1977): 478-504.

Finkel, I.L., R. Pirngruber and R.J van der Spek. "BCHP 3 (Diadochi Chronicle)." Livius. https://bit.ly/2JCLVqF.

Gaebler, Hugo. Die antiken Munzen von Makedonia und Paionia, vol. 2. Berlin: Walter de Gruyter, 1935. 
Gruen, Erich S. "The Coronation of the Diadochoi." The Craft of the Ancient Historian, 253-271. Lanham: University Press of America, 1985.

Grzybek, Erhard. Du Calendrier Macédonien au Calendrier Ptolémaïque: Problèmes de Chronologie Hellénistique. Basel: F. Reinhardt, 1990.

Hammond, N.G.L. and G.T. Griffith. A History of Macedonia, vol. II. New York: Oxford, 1979.

Hammond, N.G.L. and F.W. Walbank. A History of Macedonia, vol. III. New York: Oxford, 1988.

Hölbl, Günther. A History of the Ptolemaic Empire. London: Routledge, 2001.

Killgrove, Kristina. "Twisted knee might identify Alexander The Great's father, but some are skeptical." Forbes. July 20, 2015. https://bit.ly/2LDw2CV.

Koenen, Ludwig. "The Ptolemaic king as a religious figure." Images and Ideologies: Self-Definition in the Hellenistic World. Berkley: University of California Press, 1993, 25-115.

Lendering, Jona. "Alexander IV." Livius. Last modified 21 April 2019. https://bit.ly/ 2VitB8F.

Meeus, Alexander. "Diodorus and the chronology of the third Diadoch war." Phoenix, 66(2012): 74-96.

Merkelbach, Reinhold. "Zur ENKATOXH im Sarapeum zu Memphis." Zeitschrift für Papyrologie und Epigraphik, 103(1994): 293-296.

Mosshammer, Alden. The Chronicle of Eusebius and the Greek Chronographic Tradition. Lewisberg: Bucknell Press, 1979.

Musgrave, Jonathan. "Dust and damn'd oblivion: a study of cremation in ancient Greece." The Annual of the British School at Athens, 11(1990): 271-299.

. "The human remains from Vergina tombs I, II and III: an overview." Ancient World 22(1991): 3-9.

Petermann, J.H. and Schöne, A. (eds.) (trans). Euesebi Chronicorum Libri Duo. 1886, $3^{\text {rd }}$ ed. Zurich: Weidmann, 1999.

Porten, Bezalel, Farber, J.J. and Martin, C.J. The Elephantine Papyri in English (Documenta et Monumenta Orientis Antiqui), $2^{\text {nd }}$ edition. SBL Press: Atlanta, 2011.

Porter, Bertha and Moss, Rosalind L.B. Upper Egypt: Sites. Topographical Bibliography of Ancient Egyptian Hieroglyphic Texts, Reliefs and Paintings, 5. Oxford: Clarendon Press, 1937.

Reich, Nathaniel Julius. "A notary of ancient Thebes." The Museum Journal, 14(1923): 22-25. (University of Pennsylvania)

. "A deed of gift in 317 B.C." Mizraim, 2(1936): 57-69.

. "The papyrus archive in the Philadelphia University Museum, 1." Mizraim 7(1937), 11-19.

Révillout, Eugène. Chrestomathie Démotique, 3 vols. Paris: F. Viewig, 1880.

Schuster, Angela M.H. "Not Philip II of Macedon: an interview with Antonis Bartsiokas." Archaeology (April 2000). https://bit.ly/2VnHXob.

Skeat, Theodore Cressy. The Reigns of the Ptolemies, $2^{\text {nd }}$ edition. Münchener Beiträge zur Papyrusforschung, 39. Munich: C.H. Becke, 1968.

. "A Greek mathematical tablet." Mizraim, 3(1936): 18-25.

Smith, Sidney. "The chronology of Philip Arrhidaeus, Antigonus and Alexander IV." Revue d'Assyriologie et Archéologie, 22(1925): 179-197.

van der Spek, R.J. "CM 4 (Babylonian king list of the Hellenistic period)." Livius. https://bit.ly/2YtBmuh

Tihon, Anne. "Theon of Alexandria and Ptolemy's Handy Tables." In Ancient Astronomy and Celestial Divination, edited by N. M. Swerdlow. Cambridge: MIT Press, 1999. 
Toomer, G.J. Ptolemy's Almagest. Princeton: Princeton University Press, 1998.

Whitby, Michael and Mary Whitby. "Introduction." Chronicon Paschale 284-628 AD. Liverpool: Liverpool University Press, 1989.

Worthington, Ian. By The Spear: Philip II, Alexander the Great, and the Rise and Fall of the Macedonian Empire. Oxford: Oxford University Press, 2014.

Xirotiris, Nikolaos (N.I.) and Franziska Langenscheidt. "The cremations from the royal Macedonian tombs of Vergina." Archaiologike Ephemeris 157(1981): 142-160.

Zauzich, Karl-Theodor (K.T.). Die Ägyptische Schreibertradition in Aufbau, Sprache und Schrift der demotischen Kaufverträge aus ptolemäischer Zei. Band 1. Wiesbaden: O. Harrassowitz, 1968.

."Papyri, Demotische, Paris." Lexicon der Ägyptologie. Lieferung 25. 862874. Wiesbaden: O. Harrasowitz, 1980. 